PRODUCTION

ENGINEERING

ARCHIVES
2015, No 4, pp 13-16

ISSN 2353-5156

ISSN 2353-7779 (print version)

(online version)

Article history: $\quad$ Received: 09.11.2015 Accepted: 07.12.21015 Online: 31.12 .2015

\title{
Optimisation of quality in environmental education by means of software support
}

\author{
Katarína Čekanová ${ }^{1}$, Alena Pauliková ${ }^{1}$, Katarína Lestyánszka Škưrková ${ }^{1}$ \\ ${ }^{1}$ SlovakUniversity of Technology in Bratislava, Faculty of Materials Science and Technology in Trnava, Institute of Industrial Engineering \\ and Management, JánaBottu 25 T02, 91724 Trnava, the Slovak Republic, phone: 00421/0908646519, e-mail: katari- \\ na.cekanova@stuba.skalena.paulikova@stuba.sk,
}

\begin{abstract}
The main topic of this article is based on the fact that environmental education and edification have got an irreplaceable and preferred position within the framework of a sustainable socio-economic development. Environmental education, which is performed at technical universities, has to offer professional and methodical knowledge concerning questions of environment for students of various technical branches. This education is performed in such way that the graduates, after entering the practical professional life, will be able to participate in solutions to the new actual problems that are related to environment and its protection, as well. Nowadays, during the educational process it is also necessary to introduce technical development in a more extended rate. Taking into consideration the above-mentioned facts it is possible to say that the educational support for environmental studies is a relevant aspect, which should be integrated into the university educational process. It is a positive development trend that greater emphasis is focused on the quality of university education for the environmental engineers. Our society requires an increasing number of environmentally educated engineers who are able to participate in qualitative academic preparation, i.e. the so-called environmentalists. But the worldwide phenomena of technical development and globalisation also pose high claims for quality of their preparations including devices and computers skills. The Department of Process and Environmental Engineering at the Faculty of Mechanical Engineering, Technical University in Košice, the Slovak Republic is the institution specified and intended for quality optimisation. This Department introduced into the study programmes ("Environmental Management" and "Technology of Environmental Protection") study subjects with software support, which are oriented towards the indoor and outdoor environment and in this way the Department of Process and Environmental Engineering is integrated intensively and effectively into the area of the environmental education and edification with regard to the requirement of sustainable quality
\end{abstract}

Key words - sustainable quality, software support, environmental education, optimisation

\section{Introduction}

At the present it is well-known that environmental education and edification have an irreplaceable and preferred position in the frame of sustainable therefore socioeconomic development. At technical universities there is the important aim of environmental education to provide professional and methodical knowledge about the environment for students. It is performed in such a way that in practice they are able to participate in solutions for new actual problems which are related to environment and its protection as well. Now, in educational processes it is also necessary to introduce technical development at a higher rate. 


\section{Educational support for environ- mental studies}

It is obvious that greater emphasis is given to the quality of university education for environmental engineers. The chosen institution for quality optimisation has been selected - the department of Process and Environmental Engineering, Mechanical Engineering Faculty, Technical University in Košice, the Slovak Republic. It has also reflected and integrated information technology in its environmental education within the framework of the complex approach to education for quality development (MARKULIK, Š., NAGYOVÁ, A. 2008).

The department introduced into the study programmes ("Environmental Management" and "Technology of Environmental Protection") study subjects with software support which are oriented to indoor and outdoor environment, see Table 1. There is listed the structure of these subjects for individual study field and forms.

Table 1 Scheme of the software support subjects of the education software support at the Department of Process and Environmental Engineering (TECHNICAL UNIVERSITY IN KOŠICE 2009)

\begin{tabular}{|c|c|c|c|c|}
\hline \multicolumn{3}{|c|}{$\begin{array}{c}\text { Study programme: } \\
\text { ENVIRONMENTAL ENGINEERING }\end{array}$} & \multicolumn{2}{|c|}{$\begin{array}{c}\text { Study programme: } \\
\text { TECHNOLOGY OF ENVIRONMENTAL } \\
\text { PROTECTION } \\
\end{array}$} \\
\hline \multicolumn{5}{|c|}{ REGULAR BACHELOR STUDY } \\
\hline year & subject & $\begin{array}{l}\text { software } \\
\text { applied }\end{array}$ & subject & $\begin{array}{c}\text { software } \\
\text { applied }\end{array}$ \\
\hline 1. & & 2 & & \\
\hline 2. & CAD - Introduction of Volume Modelling & CAD & CAD - Introduction of Volume Modelling & CAD \\
\hline \multirow[t]{2}{*}{3.} & $\begin{array}{l}\text { Computer Support of Environmental } \\
\text { Protection Management }\end{array}$ & Envisim & $\begin{array}{l}\text { Computer Support of Environmental } \\
\text { Protection Management }\end{array}$ & Envisim \\
\hline & CAD - Introduction of Volume Modelling & CAD & CAD - Introduction of Volume Modelling & CAD \\
\hline \multicolumn{5}{|c|}{ REGULAR MASTER STUDY } \\
\hline \multirow{4}{*}{4.} & $\begin{array}{l}\text { Theory of Management in Environmental } \\
\text { Study }\end{array}$ & Matlab & $\begin{array}{l}\text { Theory of Management in Environmental } \\
\text { Study }\end{array}$ & Matlab \\
\hline & Intelligent Production Systems & Vensim & Machines and Devices I. & AutoCad \\
\hline & $\begin{array}{l}\text { Environmental Measuring and Monitor- } \\
\text { ing }\end{array}$ & Dialux & & \\
\hline & $\begin{array}{l}\text { Computer Networks and Database Sys- } \\
\text { tems for Environmental Study }\end{array}$ & Access & & \\
\hline \multirow{2}{*}{5.} & & 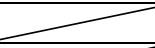 & Objectivisation of Environmental Factors & CadnaA \\
\hline & & $\longrightarrow$ & Noise and Vibrations & X Fér \\
\hline \multicolumn{5}{|c|}{ EXTERNAL BACHELOR STUDY } \\
\hline \multicolumn{5}{|l|}{1.} \\
\hline 2. & $\begin{array}{l}\text { Theory and Management Instruments in } \\
\text { Environment Study }\end{array}$ & Matlab & & \\
\hline 3. & $\begin{array}{l}\text { Computer Support of Environmental } \\
\text { Protection Management }\end{array}$ & Envisim & $\begin{array}{l}\text { Computer Support of Environmental } \\
\text { Protection Management }\end{array}$ & Envisim \\
\hline \multicolumn{5}{|c|}{ EXTERNAL MASTER STUDY } \\
\hline \multirow{4}{*}{4.} & $\begin{array}{l}\text { Theory of Management in Environmental } \\
\text { Study }\end{array}$ & Matlab & $\begin{array}{l}\text { Computer Support of Environmental } \\
\text { Protection Management }\end{array}$ & Envisim \\
\hline & $\begin{array}{l}\text { Environmental Measuring and Monitor- } \\
\text { ing }\end{array}$ & Dialux & & \\
\hline & Intelligent Production Systems & Vensim & & \\
\hline & $\begin{array}{l}\text { Computer Networks and Database Sys- } \\
\text { tems for Environmental Study }\end{array}$ & Access & & \\
\hline \multirow{2}{*}{5.} & & 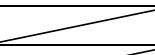 & Objectivisation of Environmental Factors & CadnaA \\
\hline & & 7 & Noise and Vibrations & X Fér \\
\hline
\end{tabular}




\section{The description brief of used software for Table 1:}

Access - software is used for a creation of databases and a data summary for environmental purposes, which can be examined statistical analysis, e.g. ecologically loaded localities and can be considered loads which are linked to an elimination of environmental damages, etc,

CAD- application serves for performing of the design documentation e.g. WWT plants, municipal and hazardous waste incinerations, recycling machines and equipments, etc.

CadnaA - program is designed for the calculation valuation, presentation and analysis of the noise loading from the industrial resources, road and railway traffic.

GIS - GIS software is designed to capture, manage, analyse, and display all forms of geographically referenced information. This application allows us to view, understand, question, interpret, and visualize our world in ways that reveal relationships, patterns, and trends in the form of maps, globes, reports, and charts.

Dialux - program application for the design and calculation of illuminating systems, which fulfil environmentally acceptable requirements and save energetic sources.

Envisim - application is used for computer support of the environmental protection management.

Matlab - universal computing program, which serves for the mathematical calculations of the practical task.

Vensim - software is designed for the modelling and simulation of the environmental and ecological processes regarding to sustainable environmental development and protection (e.g. qualification of an effectiveness of alternative power stations, the flow parameters in the WWT plants, the regulation of the animal species population.)

X Fér-software for generation of the noise maps in the environment.

Source: own study

During learning of above-mentioned study subjects, the students are aimed at an obtaining of the special knowledge and skills of software application. Then they can apply this knowledge in the integrated "Laboratory of the Objectivisation and Evaluation of Environmental Factors", which was opened by the faculty in 2008 .

In the laboratory they can verify their experiences and skills practically by means of technical measurements in a simulated working environment.

The objectivisation laboratory is equipped with devices for the noise and vibration measuring in indoor and outdoor environments, the measuring of day and artificial illumination, the measuring of electromagnetic radiation and micro-climatic conditions in the working environment. The employees of the department made a great effort at a building up of the laboratory, from the time of the idea of conception through to its construction and its practical use. Furthermore, laboratory equipment and apparatus cost a considerable expense at approximately 17,000.00 $€$ and hardware approximately $199,000.00 €$. So, the support of environmental education has got a ratio 1:12 in favour of hardware.

These expenses gives only a relative imagination of total cost. It is not possible to estimate what is the worth of the laboratory and how the quality of the complex education will be significantly influenced in the frame of environmental knowledge. This gain has already been considerable (CHOVANCOVÁJ., HARAUSOVÁ H. 2013).

By means of the laboratory seminars former students after their university graduation will be able to identify and analyse the environmental loads in industrial operational plats. Using the applied software they can measure and evaluate various influences on indoor and outdoor environments. They will be improved in an implementation of new environmental and technical solutions for used technologies (KOPAS M., ORAVEC M. 2005).

\section{Measurement of Environmental Para- meters}

The integrated "Laboratory of the Objectivisation and Evaluation of Environmental Factors" was built up step-by-step at Mechanical Engineering Faculty, the department of Process and Environmental Engineering. The laboratory is equipped with the instruments and technologies for a measurement of principal physical factors of environment. For the present there are 5 measured environmental factors:

- Noise (NORSONIC-PHONOMETERS 2009, BSWA TECHNOLOGY 2008) 
Katarína Čekanová,et al.: Optimalisation of quality in environmental education..., 4/2015

- Vibration (TESTO 400 A 435. 2009, RADIOLUX 111. 2009)

- Illumination (TESTO545. 2009)

- Electromagnetic radiation (NARDA SAFETY TEST SOLUTIONS. 2009)

- Microclimate conditions: (temperature, relative humidity, turbulence. differential and relative pressure, speed of airflow) (CRYSTAL INSTRUMENTS. 2009)

\section{Conclusion}

At present it is necessary in our society to have more environmental educated engineers who participated in qualitative academic preparation, so environmentalists. But technical development and globalisation also pose high claims for quality of their preparations including devices and computers skills (ZgodavovÁ, K., Petrík, J., ŠolC, M. 2013).

It is a challenge for academic educational institutions to build many very well equipped laboratories. The establishment of "Laboratory of the Objectivization and Evaluation of Environmental Factors" contributes to the increasing of the quality of studies and preparation of undergraduates.

It appears the fact that the department of Process and Environmental Engineering, Mechanical Engineering Faculty, Technical University in Košice works intensively and effectively on the environmental education and edification for sustainable quality (Girmanová, L., Mikloš, V., Palfy, P., Petrík, J., SÜTÖOVÁ, A., ŠOLC, M. 2009).

\section{Affiliation}

This article was elaborated within the Project KEGA: 074TUKE-4/2015 An innovative approach to legislative coordination of environmental protection through the visualization on the basis of the phenomenon Small World Networks

\section{Literature}

1. MARKULIK, Š., NAGYOVÁ, A. 2008: Quality management system + university $=$ myths or obligation? In: ORP '2008. 6 p. - ISBN 8493425656
2. TECHNICAL UNIVERSITY IN KoŠICE 2009. Engineering Faculty: Information of the studies. 2009/2010, p. 271.

3. Chovancovás., Harausová H. 2013. Education of the next generation of managers in context of green economy. Journal of economic development, environment and people. Vol.2.

4. Kopas M., Oravec M. 2005. Safe design - minimisation of loses. International Conference on Computer-Aided Ergonomics and Safety. Košice.

5. NORSONIC-PHONOMETERS 2009 [online-cited $4^{\text {th }}$

December 2009]. Accessible on

www.norsonic.com/index.php?sideID $=2431 \&$ ledd 1 $=943$.

6. BSWA TECHNOLOGY 2008 10/2008. Firm materials.

7. TESTO 400 A 435. 2009 [online - cited 7th November 2009]. Accessible on www.grimm.sk/testo 400 testo435.htm

8. RADIOLUX 111. 2009 [online - cited $7^{\text {th }}$ November 2009]. Accessible on www.gotopeo.com/doc/04peoradiolux111eng.pdf.

9. TESTO545. 2009 comfort operating luxmeter[online - cited $7^{\text {th }}$ November 2009]. Accessible on www.grimm.sk/Testo545\%20-\%20Luxmeter.htm

10.NARDA SAFETY TEST SOLUTIONS. 2009 [online cited $7^{\text {th }}$ November 2009]. Accessible on http://www.narda-sts.us/products lowfreqmeters.php

11.CRYSTAL InSTRUMENTS. 2009 [online-cited $4^{\text {th }}$ December 2009]. Accessible on www.goci.com/products.asp

12.Zgodavová, K., Petrík, J., Šolc, M. 2013. Principles concepts standards of management systems Quality, metrology and information security. 1. vyd - Saarbrücken: LAP LAMBERT Academic Publishing - - 107 p. - ISBN 978- 3-659-51719-8.

13. Girmanová, L., Mikloš, V., Palfy, P., Petrík, J., SÜTŐOVÁ, A., ŠolC, M. 2009. Nástroje a metódymanažérstvakvality. - 1. vyd - Košice: HF TU -. - 145 s. - ISBN 978-80-553-0144-0. 